\title{
PENGARUH METODE EKSTRAKSI TERHADAP KADAR TOTAL FENOLIK, KADAR TOTAL FLAVONOID DAN AKTIVITAS ANTIOKSIDAN EKSTRAK DAUN MENGKUDU (Morinda citrifolia $\mathbf{L}$.
}

\author{
Septiana Laksmi Ramayani ${ }^{1) *}$, Eka Amalia Permatasari ${ }^{2}$, Indah Novitasari ${ }^{2}$, \\ Maryana $^{2}$ \\ ${ }^{1}$ Dosen Prodi DIII Farmasi, Politeknik Katolik Mangunwijaya \\ ${ }^{2}$ Mahasiswa Prodi DIII Farmasi, Politeknik Katolik Mangunwijaya \\ Email corresponding author: septianaLR@gmail.com
}

\section{INTISARI}

Reactive Oxygen Species (ROS) yang berlebihan dapat menyebabkan hipertensi. Pencegahan risiko hipertensi adalah dengan mengkonsumsi antioksidan. Mengkudu (Morinda citrifolia L). merupakan tanaman yang terbukti secara empiris dapat menurunkan tekanan darah dan memiliki aktivitas antioksidan. Aktivitas antihipertensi daun mengkudu dipengaruhi oleh senyawa fenolik dan flavonoid. Metode ekstraksi mempengaruhi kadar senyawa dalam ekstrak. Penelitian ini bertujuan untuk mengetahui pengaruh metode ekstraksi terhadap kadar total fenol, kadar total flavonoid dan aktivitas antioksidan ekstrak daun mengkudu. Metode ekstraksi yang digunakan adalah maserasi, Microwave Assisted Extraction dan soklet. Hasil penelitian menunjukkan bahwa metode ekstraksi yang berbeda mempengaruhi kadar total fenol, kadar total flavonoid dan aktivitas antioksidan ekstrak daun mengkudu. Metode Soklet memberikan kadar total fenolik, kadar flavonoid total, dan aktivitas antioksidan tertinggi dibandingkan metode ekstraksi lainnya

Kata kunci: ekstrak daun mengkudu, metode ekstraksi, kadar total fenolik, kadar total flavonoid, aktivitas antioksidan

\begin{abstract}
Excessive Reactive Oxygen Species (ROS) can cause hypertension. Prevention of the risk of hypertension is consume an antioxidant. Noni (Morinda citrifolia L). is a plant that empirically proven to lower blood pressure and has antioxidant activity. Antihypertensive activity of noni leaves is influenced by phenolic and flavonoid compounds. The extraction method affects the levels of compound in extracts. The aims of study is determine the effect of the extraction method on the total phenolic level, total flavonoid level and antioxidant activity of noni leaf extract. The extraction methods are maceration, Microwave Assisted Extraction and Soxhlet. The results showed that the different extraction methods affected the total phenol level, total flavonoid level and antioxidant activity of the noni leaf extract. The Soxlet method provides the highest total phenolic level, total flavonoid level and antioxidant activity than other extraction methods.
\end{abstract}

Keywords: Noni leaf extract, extraction method, total phenolic level, total flavonoid level and antioxidant activity 
Corresponding author:

Septiana Laksmi Ramayani

Prodi DIII Farmasi Politeknik Katolik Mangunwijaya

J1. Gajahmada No 91. Semarang

Email: septianaLR@gmail.com

\section{PENDAHULUAN}

Hipertensi merupakan penyakit yang sering disebut sebagai sillent killer. Menurut data Riskesdas (2018), prevalensi hipertensi di Indonesia mencapai 34,1\% pada usia 18 tahun ke atas. Hipertensi dapat disebabkan oleh tingginya kadar ROS (Reactive Oxygen Species) yang menghambat aliran oksigen ke jantung dan otak. Salah satu alternatif pencegahan risiko penyakit hipertensi dapat dilakukan dengan mengkonsumsi antioksidan. Senyawa antioksidan merupakan senyawa yang dapat menghambat reaksi oksidasi dengan mengikat radikal bebas dan molekul yang sangat reaktif sehingga tubuh terlindungi dari penyakit degeneratif seperti hipertensi. Salah satu tanaman obat yang secara empiris telah banyak digunakan untuk pengobatan hipertensi dan memiliki aktivitas antioksidan adalah mengkudu (Morinda citrifolia L).

Menurut Jamaludin (2015), jus buah mengkudu yang dikonsumsi sebanyak dua kali sehari selama 3 hari pada saat 20-30 menit sebelum sarapan dan makan malam mampu menurunkan tekanan darah sebesar 10-20 mmHg. Penelitian Wigati (2015), menyebutkan bahwa selain buah mengkudu, daun mengkudu juga memiliki aktivitas farmakologi sebagai antihipertensi. Aktivitas hipertensi daun mengkudu dipengaruhi oleh adanya kandungan senyawa fenolik dan flavonoid. Kadar fenolik dan flavonoid ekstrak daun mengkudu yang diekstraksi secara maserasi sebesar $3,02 \%$ b/b GAE dan 0,46\% b/b KE (Rohman, 2006). Ekstrak daun mengkudu yang diekstraksi secara maserasi juga diketahui memiliki aktivitas antioksidan yang rendah dengan nilai IC $_{50} 244,98$ ppm (Rohman, 2007).

Aktivitas farmakologis suatu ekstrak dipengaruhi oleh kadar total senyawa aktif yang terkandung dalam ekstrak. Besarnya kandungan senyawa aktif dalam ekstrak, salah satunya dipengaruhi oleh metode ekstraksi yang digunakan. Metode ekstraksi maserasi merupakan metode ekstraksi dingin yang dilakukan dengan cara merendam sampel menggunakan pelarut yang sesuai. Pada maserasi proses ekstraksi berjalan hingga tercapainya kesetimbangan konsentrasi di dalam dan di luar sel sehingga terjadi kejenuhan pada pelarut dan senyawa yang diperoleh tidak optimal (BPOM, 2012). Salah satu cara untuk meningkatkan kandungan senyawa dan aktivitas ekstrak daun mengkudu dapat dilakukan modifikasi metode ekstraksi yang digunakan, yaitu dengan Microwave Assisted Extraction (MAE) dan metode soklet.

MAE merupakan modifikasi maserasi yang memanfaatkan radiasi gelombang mikro untuk memanaskan pelarut secara cepat dan efisien (Jain, 2011). Soklet merupakan penyarian yang dilakukan berulang-ulang dan menghindarkan terjadinya kejenuhan dengan jumlah pelarut yang relatif tetap (BPOM, 2013). Tujuan dari penelitian ini adalah untuk mengetahui pengaruh metode ekstraksi terhadap kadar total fenolik, kadar total flavonoid dan aktivitas antioksidan ekstrak daun mengkudu.

\section{METODE PENELITIAN}

Bahan yang digunakan dalam penelitian ini serbuk daun mengkudu, Metanol (Merck), asam galat (Merck), $\mathrm{FeCl}_{3}$, Folin-Ciocalteau (Merck), $\mathrm{Na}_{2} \mathrm{CO}_{3}$, serbuk $\mathrm{Mg}, \mathrm{HCl}$, kuersetin Alat (Sigma), $\mathrm{AlCl}_{3}$ (Merck), $\mathrm{CH}_{3} \mathrm{COOH}, \mathrm{DPPH}$ (Aldrich). Alat yang digunakan adalah alat gelas (Pyrex), Neraca Analitik (Mettler Toledo), microwave (Metrowealth), alat soklet, shaker, moisture analyzer (Ohaus), dan spektrofotometer UV-Vis (Mini Shimadzu 1240). 
a. Ekstraksi

Masing-masing metode ekstraksi menggunakan 40 gram serbuk daun mengkudu dan $400 \mathrm{~mL}$ pelarut metanol teknis masing-masing dilakukan tiga kali replikasi.

i. Maserasi

Ekstraksi dilakukan selama 4x24 jam dengan penggantian pelarut sebanyak $400 \mathrm{~mL}$ setiap 24 jam.

ii. Microwave Assisted Extraction

Ekstraksi dilakukan pada suhu $50^{\circ} \mathrm{C}$ selama 2 menit, secara berkala radiasi dihentikan dengan interval waktu tiap 15 detik.

iii. Soklet

Ekstraksi dilakukan pada suhu $60-65^{\circ} \mathrm{C}$ hingga cairan dalam tube extractor menjadi jernih.

Masing-masing filtrat hasil ekstraksi diuapkan diatas waterbath pada suhu $<50^{\circ} \mathrm{C}$ sampai terbentuk ekstrak kental. Masing-masing ekstrak dilakukan kontrol kualitas meliputi organoleptis, susut pengeringan dan perhitungan rendemen.

$$
\text { Rendemen }=\frac{\text { berat produk yang dihasilkan }}{\text { berat bahan baku yang digunakan }} \times 100 \%
$$

b. Uji kualitatif

i. Senyawa fenol

Sebanyak 0,1 gram ekstrak daun mengkudu dilarutkan dalam 5,0 $\mathrm{mL}$ etanol $96 \%$ dan ditambahkan dengan 2 tetes larutan $\mathrm{FeCl}_{3} 1 \%$. Terbentuknya warna hijau, merah, ungu, biru atau hitam menunjukkan adanya senyawa fenolik (Harbone, 1987).

ii. Senyawa flavonoid

Sebanyak 0,1 gram ekstrak daun mengkudu dilarutkan dalam 5,0 $\mathrm{mL}$ etanol $96 \%$ dan ditambahkan dengan 0,1 gram serbuk $\mathrm{Mg}$ dan $1 \mathrm{~mL} \mathrm{HCl}$ pekat, dan dikocok perlahan. Terbentuknya warna merah, kuning atau jingga menunjukkan adanya senyawa flavonoid (Hanani, 2015).

iii. Aktivitas antioksidan

Sebanyak 0,1 gram ekstrak daun mengkudu dilarutkan dalam 5,0 mL etanol $96 \%$ dan ditambahkan dengan $4 \mathrm{~mL}$ larutan DPPH $(0,075 \mathrm{mM})$. Terbentuknya warna kuning menunjukkan adanya aktivitas antioksidan (Molyenux, 2004).

c. Uji kuantitatif

i. Senyawa fenol

Sebanyak $1 \mathrm{~mL}$ dari masing-masing deret baku larutan asam galat dan larutan ekstrak dimasukkan dalam masing-masing tabung, ditambahkan $5 \mathrm{~mL}$ reagen Folin-Ciocalteau (1:10) dan $4 \mathrm{~mL} \mathrm{Na}_{2} \mathrm{CO}_{3} 1 \mathrm{M}$. Larutan diinkubasi selama 25 menit dan diukur absorbansinya pada panjang gelombang $748,20 \mathrm{~nm}$. Kadar total fenolik dinyatakan dalam GAE sebagai miligram ekivalensi asam galat per gram ekstrak. Kadar total fenolik dapat dihitung dengan persamaan (2).

$$
\text { Kadar Senyawa }=\frac{\mathrm{c} \mathrm{x} \mathrm{v} \mathrm{x} \mathrm{fp}}{\text { gram ekstrak }} \times 100 \%
$$

Keterangan :

$\mathrm{C}=$ konsentrasi

$\mathrm{V}=$ volume ekstrak

$\mathrm{fp}=$ faktor pengenceran

$\mathrm{g}=$ berat sampel yang digunakan $(\mathrm{g})$ 
ii. Senyawa flavonoid

Sebanyak $1 \mathrm{~mL}$ dari masing-masing deret baku larutan kuersetin dan larutan ekstrak dimasukkan dalam masing-masing tabung, ditambahkan $1 \mathrm{~mL} \mathrm{AlCl}_{3} 10 \%$ dan $8 \mathrm{~mL}$ $\mathrm{CH}_{3} \mathrm{COOH}$ 5\%. Larutan diinkubasi selama 14 menit dan diukur absorbansinya pada panjang gelombang 413,90 nm. Kadar total flavonoid dinyatakan dalam KE sebagai miligram ekivalensi kuersetin per gram ekstrak. Kadar total flavonoid dapat dihitung dengan persamaan (2).

iii. Aktivitas antioksidan

Sebanyak $0,1 \mathrm{~mL}$ dari masing-masing deret baku larutan asam galat dan larutan ekstrak dimasukkan dalam masing-masing tabung, ditambahkan $4 \mathrm{~mL}$ larutan DPPH $0,075 \mathrm{mM}$. Absorbansi larutan diukur pada panjang gelombang 515,9 nm. Aktivitas antioksidan dinyatakan dalam persentase aktivitas antioksidan dan dihitung dengan persamaan (3).

$$
\text { Persentase Aktivitas Antioksidan }=\frac{\text { absorbansi blanko-absorbansi sampel }}{\text { absorbansi blanko }} \times 100 \%
$$

d. Analisis data

Data yang diperoleh dianalisa secara statistik dengan uji One way Analysis of Variance dan dilanjutkan dengan uji Post-Hoc Bonferroni dengan taraf kepercayaan 95\%.

\section{Hasil dan Pembahasan}

Ekstrak daun mengkudu tiap metode ekstraksi dilakukan kontrol kualitas untuk menjaga mutu dan kualitas dari ekstrak yang dihasilkan. Hasil kontrol kualitas ekstrak daun mengkudu dapat dilihat pada Tabel 1.

\begin{tabular}{|cccc}
\multirow{2}{*}{$\begin{array}{c}\text { Tabel 1. Kontrol Kualitas Ekstrak Daun } \\
\text { Parameter }\end{array}$} & \multicolumn{3}{c}{$\begin{array}{c}\text { Mengkudu pada Berbagai Metode Ekstraksi } \\
\text { Metode ekstraksi }\end{array}$} \\
\cline { 2 - 4 } & $\begin{array}{c}\text { Maserasi } \\
\text { (Ekstrak A) }\end{array}$ & $\begin{array}{c}\text { MAE } \\
\text { (Ekstrak B) }\end{array}$ & $\begin{array}{c}\text { Soklet } \\
\text { (Ekstrak C) }\end{array}$ \\
\hline Organoleptis & & Ekstrak kental & Ekstrak kental \\
a. Bentuk & Ekstrak kental & Hijau kehitaman & Hijau kehitaman \\
b. Warna & Hijau kehitaman & Khas & Khas \\
c. Bau & Khas & Pahit & Pahit \\
d. Rasa & Pahit & $2,62^{\mathrm{a}}$ & $5,08^{\mathrm{b}}$ \\
Susut pengeringan & $1,99^{\mathrm{a}}$ & $20,23^{\mathrm{a}}$ & $25,21^{\mathrm{b}}$ \\
\hline
\end{tabular}

Subscript yang berbeda menunjukkan adanya perbedaan bermakna $(p<0,05)$

Perbedaan metode ekstraksi menunjukkan organoleptis yang sama. Warna ekstrak yang dihasilkan menunjukkan adanya perubahan warna dari warna serbuk simplisia yaitu berwarna hijau menjadi hijau kehitaman. Perubahan warna disebabkan karena adanya reaksi oksidasi akibat pemanasan saat penguapan filtrat menjadi ekstrak. Rasa pahit ekstrak daun mengkudu karena adanya senyawa alkaloid (Halimah dkk, 2018). Senyawa alkaloid merupakan golongan senyawa yang bersifat basa dan mengandung unsur nitrogen $(\mathrm{N})$ dan berasa pahit.

Perbedaan metode ekstraksi menunjukkan adanya perbedaan yang signifikan $(p<0,05)$ pada pengujian susut pengeringan dan rendemen. Rendemen tertinggi ditunjukkan pada metode ekstraksi soklet. Metode soklet merupakan metode ekstraksi yang menggunakan pelarut yang selalu baru dengan bantuan alat khusus dan berjalan secara kontinyu, sehingga dapat meminimalisir terjadinya kejenuhan dan menyebabkan senyawa yang tersari semakin banyak. Hasil analisa statistik susut pengeringan dan rendemen pada metode maserasi dan MAE menunjukkan perbedaan yang tidak 
signifikan $(p>0,05)$ karena kedua metode tersebut memiliki prinsip yang sama yaitu perendaman sehingga ketika konsentrasi di dalam sel dan diluar sel setimbang (jenuh) tidak akan terjadi perpindahan massa lagi dari dalam sel simplisia ke pelarut.

Masing-masing ekstrak dilakukan uji kualitatif sebagai uji pendahuluan pada uji kuantitatif. Hasil uji kualitatif ekstrak daun mengkudu menunjukkan hasil positif senyawa fenolik yaitu terbentuknya warna coklat kehitaman. Perubahan warna terjadi karena senyawa fenol bereaksi dengan $\mathrm{FeCl}_{3}$ membentuk senyawa kompleks. Senyawa kompleks dapat berwarna karena adanya transisi elektron dan ion pusat akibat adanya ligan (Sahoo dkk, 2012). Baku pembanding yang digunakan adalah asam galat, hasil pengujian menunjukkan terbentuknya warna biru setelah penambahan dengan $\mathrm{FeCl}_{3}$.

Hasil uji kualitatif ekstrak daun mengkudu menunjukkan hasil positif senyawa flavonoid yang ditunjukkan dengan adanya perubahan warna ekstrak yang semula berwarna hijau kehitaman menjadi kuning jingga. Perubahan warna terjadi karena logam $\mathrm{Mg}$ dan $\mathrm{HCl}$ pekat mereduksi inti benzopiron pada flavonoid dan membentuk garam flavilium (Hanani, 2015). Hasil pengujian menunjukkan warna yang hampir sama pada pengujian baku pembanding kuersetin yaitu terbentuknya warna kuning jingga. Hasil uji kualitatif aktivitas antioksidan menunjukkan hasil positif dengan adanya perubahan warna larutan DPPH dari ungu menjadi kuning setelah penambahan ekstrak karena adanya kemampuan mengikat elektron yang tidak berpasangan dari senyawa radikal (Molyneux, 2004). Hasil uji kualitatif ekstrak pada berbagai metode dapat dilihat pada Tabel 2.

Tabel 2. Hasil Uji Kualitatif Ekstrak Daun Mengkudu pada Berbagai Metode Ekstraksi

\begin{tabular}{cccccc}
\hline Pengujian & $\begin{array}{c}\text { Warna blanko } \\
\text { larutan ekstrak }\end{array}$ & Pereaksi & \multicolumn{2}{c}{ Warna larutan ekstrak + pereaksi } \\
Maserasi & MAE & Sokletasi \\
\hline Fenolik & Coklat & $\mathrm{FeCl}_{3}$ & coklat kehitaman & coklat kehitaman coklat kehitaman \\
Flavonoid & Coklat & $\mathrm{Mg}+\mathrm{HCl}$ & kuning jingga & kuning jingga & kuning jingga \\
Antioksidan & Coklat & $\mathrm{DPPH}$ & kuning & kuning & kuning \\
\hline
\end{tabular}

Penentuan kadar total fenolik ekstrak daun mengkudu menggunakan asam galat sebagai baku pembanding. Persamaan regresi linier asam galat yang diperoleh adalah $y=0,098 x+0,0493$ dengan koefisien relasi $r=0,999$. Nilai koefisien relasi yang mendekati 1 menunjukkan bahwa kurva baku yang diperoleh semakin mendekati linier (Gandjar dan Rohman, 2007).

Penentuan kadar total flavonoid ekstrak daun mengkudu menggunakan kuersetin sebagai baku pembanding. Kuersetin merupakan flavonoid golongan flavonol (Chang dkk, 2002). Persamaan regresi linier yang diperoleh pada kurva baku kuersetin adalah $y=0,005 x+0,143$ dengan koefisien relasi $\mathrm{r}=0,999$.

Aktivitas antioksidan ekstrak daun mengkudu dilakukan dengan metode DPPH. Prinsip kerja metode DPPH adalah adanya atom hidrogen dari senyawa antioksidan yang berikatan dengan elektron bebas pada senyawa radikal sehingga menyebabkan perubahan dari radikal bebas (diphenylpicrylhydrazyl) menjadi senyawa non-radikal (diphenylpicrylhydrazine). Adanya senyawa antioksidan menyebabkan perubahan warna larutan DPPH dari warna ungu gelap menjadi warna kuning. Makin kuat senyawa antioksidan untuk menangkal radikal DPPH, makin pudar warna yang teramati (Setiawan dkk, 2018). 
Tabel 2. Kadar Total Fenolik, Kadar Total Flavonoid dan Aktivitas Antioksidan Ekstrak Daun Mengkudu pada Berbagai Metode Ekstraksi

\begin{tabular}{lccc}
\hline \multicolumn{1}{c}{ Parameter } & \multicolumn{3}{c}{ Metode ekstraksi } \\
\cline { 2 - 4 } & $\begin{array}{c}\text { Maserasi } \\
(\text { Ekstrak A) }\end{array}$ & $\begin{array}{c}\text { MAE } \\
(\text { Ekstrak B) }\end{array}$ & $\begin{array}{c}\text { Soklet } \\
(\text { Ekstrak C) }\end{array}$ \\
\hline $\begin{array}{l}\text { Kadar Total Fenolik } \\
\text { (mgGAE/g ekstrak) }\end{array}$ & $6,03 \pm 0,01^{\mathrm{a}}$ & $8,80 \pm 0,01^{\mathrm{b}}$ & $11,50 \pm 0,28^{\mathrm{c}}$ \\
\hline $\begin{array}{l}\text { Kadar Total Flavonoid } \\
\text { (mgKE/g ekstrak) }\end{array}$ & $2,07 \pm 0,04^{\mathrm{a}}$ & $6,45 \pm 0,02^{\mathrm{b}}$ & $10,51 \pm 0,04^{\mathrm{c}}$ \\
\hline Aktivitas Antioksidan $(\%)$ & $6,64 \pm 0,12^{\mathrm{a}}$ & $15,55 \pm 0,08^{\mathrm{b}}$ & $27,78 \pm 0,04^{\mathrm{c}}$ \\
\hline Subscript yang berbeda menunjukkan adanya perbedaan signifikan $(p<0,05)$
\end{tabular}

Tabel 2 menunjukkan bahwa perbedaan metode ekstraksi memberikan perbedaan yang signifikan terhadap kadar total fenolik, kadar total flavonoid dan aktivitas antioksidan. Persentase aktivitas antioksidan menunjukkan besarnya aktivitas hambatan radikal bebas yang dapat dihasilkan oleh senyawa dalam ekstrak. Semakin banyak senyawa radikal bebas (DPPH) yang dihambat maka semakin besar persentase aktivitas antioksidan yang dihasilkan. Kadar total fenolik, kadar total flavonoid dan aktivitas antioksidan tertinggi ditunjukkan pada metode ekstraksi soklet, diikuti MAE dan maserasi. Hasil ini berbanding lurus dengan rendemen ekstrak yang dihasilkan yaitu pada metode ekstraksi soklet, MAE dan paling kecil pada maserasi. Rendemen tertinggi menghasilkan kadar senyawa dan aktivitas yang paling tinggi pula. Semakin banyak rendemen yang dihasilkan maka semakin banyak pula kadar senyawa yang terkandung dan semakin besar aktivitasnya. Aktivitas antioksidan ekstrak daun mengkudu diduga kuat karena adanya senyawa fenolik dan flavonoid dalam ekstrak tersebut (Rao dan Subramanian, 2009). Senyawa fenol akan bereaksi dengan radikal bebas dengan mendonorkan atom hidrogen $(\mathrm{H})$ kepada radikal DPPH sehingga tereduksi menjadi bentuk yang lebih stabil. Aktivitas antioksidan senyawa fenolik juga berkaitan dengan kemampuannya untuk mengkhelat logam ion yang terdapat dalam produksi radikal bebas (Pereira dkk, 2009). Senyawa flavonoid mengandung gugus cathecol (O-dihidroksi) pada cincin B yang memberikan kemampuan penangkapan radikal bebas yang tinggi (Middleton dkk, 2000).

\section{KESIMPULAN}

Perbedaan metode ekstraksi berpengaruh signifikan terhadap kadar total fenolik, kadar total flavonoid dan aktivitas antioksidan ekstrak daun mengkudu. Hasil tertinggi diperoleh pada metode ekstraksi soklet, diikuti MAE dan maserasi.

\section{DAFTAR PUSTAKA}

BPOM, R.I., 2012, Pedoman Teknologi Formulasi Sediaan Berbasi Ekstrak, Vol. 2., Badan Pengawas Obat dan Makanan Republik Indonesia:Jakarta

Chang, C.C., Yang., M.H., Wem, H.M. \& Chern, J.C., 2002, Estimation of Total Flavonoid Content in Propolis by Two Complementary Colorimetric Methods, Journal of Food and Drug Analysis, Vol. 10 (3):178-182.

Halimah, H., Suci, D.M., Wijayanti, I., 2018, Studi Potensi Penggunaan Daun Mengkudu (Morinda citrifolia L.) Sebagai Bahan antibakteri Escherichia coli dan Salmonella typhimurium, Jurnal Ilmu Pertanian Indonesia, Vol 24 (1): 56-64

Hanani, E., 2014, Analisis Fitokimia, Buku Kedokteran EGC:Jakarta

Harbone, J.B., 1987, Metode Fitokimia : Penuntun Cara Modern Menganalisa Tumbuhan, Penerbit 
ITB:Bandung

Jamaludin, 2015, Pemberian Mengkudu Dalam Menunrunkan Tekanan Darah pada Pasien Hipertensi di Dukuh Susukan Desa Samirejo Kecamatan Dawe Kabupaten Kudus, Jurnal Profesi dan Keperawatan.

Middleton Jr. E., Kandaswami, C., and Theoharis, C.T., 2000, The Effects of Plant Flavonoid on Mammalian Cells: Implication for Inflamation, Heart Disease and Cancer, Pharmacol Rev., $52(4), 673-751$

Molyneux, P., 2004, The Use of The Stable Free Radical Diphenylpicrylhydrazyl (DPPH) for Estimating Antioxidant Activy, Journal of Science and Technology, 26(2), 211-219

Pereira, D., M., Valentao, P., Pereira, J., A., dan Andrade, B., 2009, Phenolics : From Chemistry to Biology, Molecules, 14, 2202-2211.

Rao, U.S.M., dan Subramanian, S. 2009, Biochemical Evaluation of Antihyperglycemic and Antioxidative Effects of Morinda citrifolia Fruit Extract Studied in Streptozotocin-Induced Diabetic Rats, Medicinal Chemistry Research, 18:433-446.

Riskesdas, 2018. Badan Penelitian dan Pengembangan Kesehatan. Kemenkes RI : Jakarta.

Rohman, A., Riyanto, S. dan Utari, D., 2006. Antioxidant Activities Total Phenolic and Flavonoid Contents Of Ethyl Acetate Extract Of Mengkudu (Morinda citrifolia L.) Fruit and Its Fractions. Majalah Farmasi Indonesia. 17 : 136142

Rohman, Abdul., Sugeng. R., Nurul K.H., 2007. Aktivitas Antioksidan Kandungan Fenolik Total dan Flavonoid Total Daun Mengkudu (Morinda citrifolia L.), Agritech (27)

Sahoo, B., Nayak, N. C., Samantaray, A., and Pujapanda, P. K., 2012. Inorganic Chemistry. PHI Learning Pvt : Dehli

Setiawan F., Yunita O., Kurniawan A., 2018, Uji Aktivitas Antioksidan Ekstrak Etanol Kayu Secang (Caesalpinia sappan) Menggunakan Metode DPPH, ABTS dan FRAP, Media Pharmaceutuca Indonesiana, Vol 2 (2), 82-89.

Wigati. D., 2015. Efek Ekstrak Etanolik Daun dan Buah Morinda citrifolia L. Terhadap Tekanan Darah dan Gambaran Hispatologi Ginjal Tikus Hipertensi Terinduksi Deksametason. Tesis. Universitas Gajah Mada : Yogyakarta. 